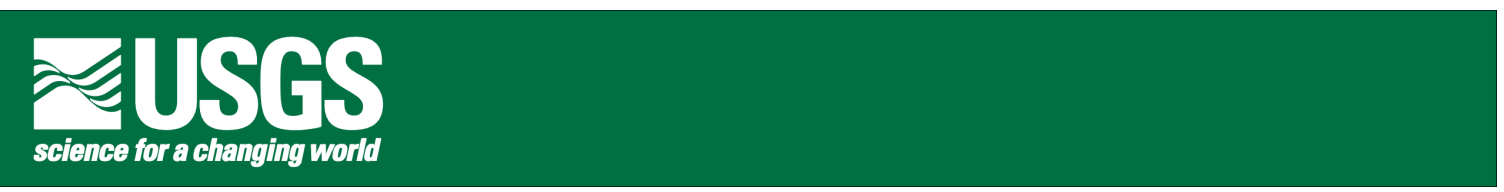

\title{
Managing and Protecting Aggregate Resources
}

by William H. Langer ${ }^{1}$

Open-File Report 02-415

2002

This report is preliminary and has not been reviewed for conformity with U.S. Geological Survey editorial standards or with the North American Stratigraphic Code. Any use of trade, firm, or product names is for descriptive purposes only and does not imply endorsement by the U.S. Government.

\section{U.S. DEPARTMENT OF THE INTERIOR \\ U.S. GEOLOGICAL SURVEY}

\author{
${ }^{1}$ Denver, Colorado
}




\section{Managing and Protecting Aggregate Resources}

\section{Introduction}

Over the past century the growth of American cities and towns, and the construction and maintenance of the highways and byways between those population centers, created a demand for enormous amounts of natural aggregate. Over that same period of time circumstances and events have taken place that have complicated the ability of producers to meet the increasing need for aggregate.

Products derived from rocks provide essential materials for society - materials that we need to maintain our current lifestyle. Rock products are used in one form or another for construction of highways, bridges, houses, and other buildings; in industry for making steel, glass, and other consumer products; for environmental applications such as filtering sewage and scrubbing flue gasses during generation of electricity; and for numerous agricultural, metallurgical, and pharmaceutical purposes (Langer and Glanzman, 1993). For many uses there is no readily available substitute.

Natural aggregate is the most valuable non-fuel mineral commodity in the world (Lüttig, 1994). The estimated value of non-fuel mineral commodities produced in the United States during 2001 was \$39 billion. Natural aggregate (sand, gravel, and crushed stone) accounts for $\$ 14.5$ billion, or over one-third of this value, and dwarfed the $\$ 5.5$ billion value of copper, gold, and silver combined (U.S. Geological Survey, 2002).

Around the beginning of the 20th century, annual aggregate production in the United States was about $50 \mathrm{Mt}$, or about $0.5 \mathrm{t}$ per person per year. By the end of the $20^{\text {th }}$ century, annual aggregate production had increased over 50 fold, to more than $2.5 \mathrm{Bt}$, or about $10 t$ per person per year. Today, over a third of the individual states in the United States each produce more aggregate than the entire Nation did at the turn of the century. The general trend over the past century has been for aggregate consumption in the United States to grow every year except during recessions, and it is projected that we will use as much aggregate in the next 25 years as we have used in the previous 100 years (Tepordei, 1997).

Aggregate occurs where Mother Nature put it, not necessarily where we need it, and even though potential sources of aggregate are widely distributed throughout the world, there are large regions where natural occurrences of aggregate are non-existent (Langer, 1988). Furthermore, even if sources of aggregate are present, they must meet certain quality parameters before they can be put to use. Those quality parameters are determined by the final application, and can restrict the development of otherwise high quality aggregate.

There are potential environmental impacts associated with aggregate extraction including the conversion of land use, changes to the landscape, loss of habitat, noise, dust, blasting effects, erosion, and sedimentation. Most of the environmental impacts associated with aggregate mining are relatively benign. However, extracting aggregate from some areas may alter the geologic conditions, which, in turn, may alter the dynamic equilibrium of the area, resulting in cascading environmental impacts (Langer, 2001). By employing best management practices, most environmental impacts can be controlled, mitigated, or kept at tolerable levels and can be restricted to the immediate vicinity of the 
aggregate operation. Nevertheless, some otherwise high quality aggregate resources may not be developed because of environmental reasons.

Aggregate is a high-bulk, low unit value commodity that derives much of its value from being located near the market. Thus, it is said to have a high place value (Bates, 1969). Transporting aggregate long distances can add significantly to the overall price of the product (Leighton, 1991). For example, a city of 100,000 can expect to pay an additional \$1.3 million for each additional 10 miles that the aggregate it uses must be hauled (Ad Hoc Aggregate Committee, 1998). Therefore, aggregate operations frequently are located near population centers and other market areas.

Despite society's dependence on natural aggregate, urban expansion often works to the detriment of the production of those essential raw materials. "Resource sterilization" occurs when the development of a resource is precluded by another existing land use. For example, aggregate resources that exist under a housing development or shopping center commonly will not be extracted.

Bauer (1993) stated that probably the most serious reason for the loss of aggregate resources is the fact that, while resources such as vegetation, soils, archeological sites, endangered species, and so forth are recognized in the community comprehensive planning process as resources of community value, aggregates are not.

Furthermore, citizens have their own ideas on how to use the land. Many citizens do not support mining, in part because they do not recognize the dependence of society on aggregate. Personal use is very little, if any, and individuals may not recognize aggregate mining as a necessary land use, even though the need for the commodity is constant. A survey conducted during 1994 (Bingham, 1994) concluded that the public in general believes mining exploits workers, harms the environment, harms the people in nearby communities, and has little personal benefit to the individual. For these and other reasons, citizens may prefer that stone and sand and gravel not be mined nearby (Langer and Glanzman, 1993). This "not in my back yard" syndrome may restrict aggregate development.

To protect citizens from the impacts of mining, governments may require permits or impose regulations to control aggregate development. Poulin and others (1994) concluded that permits and regulations restrict development or expansion of aggregate in established areas more than actual resource availability. Weaver (1995) reports that no new crushed stone quarries have been permitted in Connecticut in 15 years, and indications are that estimated sand and gravel supplies in New England could be reduced by at least 90 percent by reason of increased zoning and environmental restrictions (New England Governors' Conference, 1995).

As one approach to avoid the impacts of sterilization and encroachment, aggregate producers are turning to the development of superquarries, which are aggregate operations that produce over 5Mt of aggregate per year (Langer, 2002; Bliss and others, 2002). Superquarries can concentrate operations in remote areas away from public view, take advantage of lower production costs and, if appropriately located, utilize rail or water transport methods. During 2000, the U.S. had 19 crushed stone superquarries (Tepordei, 2000) and three sand and gravel superquarries (Bolen, 2000). Acquisitions are also expected to continue, especially as a means to obtain permitted reserves. The U.S. Bancorp Piper Jaffray Company expects that by about 2005, the top five aggregate producers in the United States will have 40 percent of the total market (Reilly, 2000). 


\section{Resource Sterilization}

It is likely that we will continue to extract and consume large amounts of natural aggregate, and that much of the aggregate will come from large operations requiring large areas of land. This underscores the problems associated with aggregate resource sterilization and the necessity to maintain access to future supplies of aggregate resources.

When the aggregate industry was young, protecting access to aggregate resources was not necessary. During the late 1800's, the relatively low demand for aggregate combined with the lack of specifications allowed for the casual discovery of aggregate. Prospecting commonly was unnecessary, and aggregate frequently was identified through related activities such as building of railroads or canals, and digging cellars or wells for houses (Langer, 1998).

The growth of cities and the roads connecting those cities created a new demand for aggregate resources. At the start of the $20^{\text {th }}$ century, there were only six metropolitan areas in the United States with a population over one million -Boston, Chicago, New York, Philadelphia, Pittsburgh, and Washington-Baltimore. At the start of the $21^{\text {st }}$ century there were 49 metropolitan areas that exceeded one million residents. In the United States, the construction of good interurban roads began in earnest during the late $19^{\text {th }}$ century. The first complete survey of America's roads, finished in 1904, reported two million miles of rural public roads in the country, fewer than 154,000 miles of which were surfaced with either gravel, stones, or paving materials. Today there are nearly four million miles of roads in the United States; nearly 2.5 million are paved and most of the rest have some type of stone or gravel surface. It is not surprising, then, that aggregate started to be used in large amounts at about the same time that the construction of cities and roads began to grow. Aggregate production in the United States doubled between 1905-1910, doubled again between 1910-1925, again between 1925-1950, and again between 1950-1960.

Geologists recognized that casual exploration was no longer an acceptable means to locate quality construction materials, and that a systematic study of the occurrence and quality of aggregate resources was necessary to support the growth of the highway system. During 1889, R.T. Hill prepared a report on road materials of the Black Prairie regions of Texas. This report was shortly followed by similar reports for North Carolina in 1892 and 1893, and Florida in 1893 (Kiersch, 1955). The Fifteenth Annual Report and Sixteenth Annual Report of the United States Geological Survey both contain reports by N.S. Shaler $(1895,1896)$ describing the geology of common roads and of road building materials. Shaler (1895) pointed out the need for geologic knowledge of aggregate properties and the necessity for having the resources located near the point of use to save transportation costs. Probably the most extensive investigation relating the composition of the rock to engineering characteristics was a 1913 statewide survey of aggregate resources in Ohio (Marshall and Maxey, 1950). By 1918, at least 49 reports describing road-building materials for at least 24 different states had been published by federal agencies and state geological surveys (Kiersch, 1955).

The rapid expansion of cities resulted in sterilization of aggregate resources. One of the first published descriptions of human encroachment causing sterilization of aggregate resources was in Business Booming in the West, (Lenhart, 1947). The paper 
described how zoning accompanied sprawling growth, and how that situation created problems for access to aggregate. Seven years later, Thoenen (1954) reported that sand and gravel deposits near cities were becoming depleted and that operators were using portable plants to mine deposits near highway projects to preserve their supplies at city plants for city markets. Because of depletion of deposits, encroachment of residential areas, and increasing stringency of specifications, operators had to consider more adequate and accurate methods of exploration.

Across the country the problem of sterilization worsened, and by 1957 sterilization had reached such serious proportions in Denver that the Colorado Sand and Gravel Producers Association produced an air photo publication to call attention to the diminishing sand and gravel reserves. By 1960, the Third Edition of Industrial Minerals and Rocks (and all subsequent editions) identified encroachment as an issue limiting aggregate (Lenhart, 1960). In the paper Quarry Site Surveys in Relation to Country Planning, Shadmon, (1968) pointed out that there were many countries where opening new quarries was practically impossible, and that the impacts of sterilization severely impacted aggregate availability. He called for countrywide planning to forecast longterm quarry product needs.

Geologists and engineers became concerned with the situation and documented the effects of sterilization in various parts of the country including Anne Arundel County, Md. (Kuff, 1984), Boulder, Colo. (Crosby and others, 1978), Chicago, Ill. (Mikulic and Goodwin, 1984), Connecticut (Siebert, 1969), Denver, Colo. (Soule, 1974), Los Angeles, Calif. (Goldman, 1959), metropolitan New York, N.Y., (Hudec, 1969), and Ontario, Canada (Guillet, 1980).

\section{Resource Protection}

During the 1970's some state and local governments realized that a readily available supply of quality aggregate was necessary to maintain the infrastructure and recognized that sterilization and citizen opposition were threats to aggregate availability. A number of attempts were made at protecting aggregate resources from sterilization (Werth, 1980). Some local governments created special extraction districts where extraction was allowed by right, and all other uses were controlled through a conditional use. In other areas, aggregate properties were placed in overlay zones where resource extraction is allowed while simultaneously preserving the long-term land use for the area. Some local governments zoned aggregate properties as agriculture or industrial, and permitted extraction as a conditional or special use.

The problems associated with encroachment of developments on aggregates operations, and one how one county responded to those problems, can be illustrated by Tooele County, Utah (Nicole Cline, Division Manager and County Planner, Division of Planning and Zoning, Tooele County, Utah, oral commun., 2002). Between 1990 and 2000 the population in Tooele County, Utah, increased 51.3 percent to 40,735 residents. Construction in many of the subdivisions started during the 1960's and 1970's stopped during the 1980's, but was rejuvenated during the 1990's, creating a great increase in demand for aggregate. At the same time the expanding neighborhoods began encroaching on the existing aggregate operations. The new residents considered the noise, dust, unsightly appearance, and traffic associated with the aggregate operations, and the odors 
from the asphalt plants, to be a nuisance. Pressure was brought on operators and county leaders to restrict operations. In many instances the local operators departed the site for deposits farther away from development, and found themselves leap-frogging away from the persistently encroaching developments. The situation reached critical limits during the late 1990's when residents, producers, and the county became entangled in litigation. During 2001, the Tooele County Commission approved the addition of Chapter 27 Mining, Quarry, Sand and Gravel Excavation Zone (MG-EX) to the Uniform Zoning Ordinance of Tooele County. The new zoning district allows and protects the crushed stone and sand and gravel industry while protecting the environment. The zone was designed to assure that aggregate operations do not impact adjoining uses, and are not encroached upon by surrounding non-compatible land uses.

The new zoning approach provides public input, and includes strict requirements for the application, operation, and reclamation of pits or quarries. Once the zoning is in place the process of getting final approvals for operation is streamlined, and producers are assured the opportunity for continual operation (renewable every five years), as long as they follow best management practices. The advantage is aggregate extraction and related activities are separated from other non-compatible land uses.

It is too early to adequately assess the effectiveness of the new ordinance, but in general, the industry appears satisfied with the new approach to zoning. The Associated General Contractors of America - Utah Chapter has presented the ordinance to other jurisdictions to consider as a model for creating a new mineral extraction zone. To date, aggregate operators have submitted applications to have three properties rezoned as MGEX; two have been approved and the third is in process. Tooele County initiated an action to rezone approximately 10,000 acres containing extensive aggregate deposits, but the application was withdrawn when it became obvious during the public hearing process that the county would not be able to reach consensus among the citizens. As a result the County has decided to refrain from making large-scale rezoning of the MG-EX zone on its own.

Some state governments, including Colorado (Schowchow and others, 1974), California (Beebe, 1998), Minnesota (Ad Hoc Aggregate Committee, 1998), and Washington (Lingley and Jazdzewski, 1994), have enacted legislation to help maintain access to prime aggregate resources. Legislations have met with variable success, in part because the legislation may not have given the authority to make requirements binding.

Colorado - During 1973, the Colorado legislature recognized that sand and gravel resources in the Denver area were rapidly being sterilized by conflicting land uses, and passed House Bill 1529. That act declared: 1) the State's commercial mineral deposits were essential to the State's economy, 2) the populous counties of the State faced a critical shortage of such deposits, and 3) such deposits should be extracted according to a rational plan, calculated to avoid waste and cause the least practical disruption to the ecology and quality of life of the citizens. The Colorado Geological Survey published an atlas of maps showing the quality and availability of aggregate resources in the populous Front Range counties (Schwochow and others, 1974). But in spite of the availability of these maps, H.B. 1529 did not succeed at protecting aggregate resources in the Denver area (Schwochow, 1980). Many of the plans prepared by the counties protected citizens from mining, but did little to protect mineral resources from citizens. The U.S. Department of Labor (1981) pointed out that resource availability in 
the Front Range continued to decline, and blamed the decline on adverse zoning, noncompliance with H.B. 1529, increased demand, inadequate grain size to meet specifications, and environmental and visual concerns. Although a number of permits have been granted to expand existing quarries, there have been no permits to open new crushed stone quarries along the Colorado Front Range since 1978 (Wilburn and Langer, 2000).

California - In 1975, California implemented the Surface Mining and Reclamation Act (SMARA) (Beeby, 1998). Under SMARA, the California Division of Mines and Geology is mandated to classify specified lands within the State on the basis of mineral content. SMARA does not require that aggregate resources be permitted, but it provides decision-makers with the information upon which to base various land-use evaluations. Having the State, an unbiased third party, prepare the classifications has a distinct advantage in that accurate, objective, quantified mineral-resource data reduces the ability of special interest groups to influence the process. Anecdotal evidence indicates that use of SMARA has been effective at facilitating the permitting process, increasing the life span on renewed use permits, and in the discovery and opening of new deposits. Furthermore, SMARA maps and reports have been used in consideration of proposed permits (as opposed to a planning approach) to prevent a change of land use that would preclude aggregate development. For example, the loss of a significant section of alluvial gravels that were a county's sole source of Portland cement concrete grade aggregate was prevented through use of SMARA information (Beebe, 1998).

Minnesota - During1984, Minnesota Statute 84.94 was enacted to protect aggregate resources; to promote orderly and environmentally sound development; to spread the burden of development; and to introduce aggregate resource protection into local comprehensive planning and land use controls. The legislation initiated countylevel identification and characterization of aggregate resources, and directed county planning authorities to use the information to consider the protection of identified aggregate resources in their planning decisions. Substantial progress was made regarding the identification and mapping of aggregate resources, but by the late 1990's, little progress had been accomplished to protect aggregate resources (Ad Hoc Aggregate Committee, 1998).

During 1998, the Minnesota Legislature created the "Aggregate Resources Task Force" to examine issues concerning the need for and use of the state's aggregate resources, ( Laws of Minnesota 1998, Chapter 401, Section 50). The Task Force Final Report (Aggregate Resources Task Force, 2000) made a number of recommendations designed to facilitate the task of making wise use of aggregate resources. The actions recommended are typical of those used for sustainable resource management, and include: 1) Best Management Practices, 2) reclamation standards, 3) mine planning and permits, 4) native prairie conservation, 6) aggregate planning and protection, 7) registration of commercial aggregate deposits with the State Department of Natural Resources, 8) aggregate resource mapping, 9) leasing aggregate reserves by State Department of Transportation, 10) compensating host communities, 11) incentives for recycling, and 12) encouraging transportation of aggregates by bulk carriers.

Progress continues to be made regarding the identification and mapping of aggregate resources, as exemplified by the Aggregate Resources Inventory of the SevenCounty Metropolitan Area, Minnesota (Southwick and others, 2000) as well as other 
county aggregate resource inventories. The aggregate mapping program provides citizens, local government land use planners, the construction industry, and environmental groups with specific county-wide information on the location and quality of aggregate resources.

Washington - The Washington Growth Management Act (Revised Code of Washington 36.70A), adopted in 1990, requires county and municipal governments to undertake comprehensive land-use planning. Counties that do not comply risk losing some sources of funding from the state. To balance their planning goals, local governments are required to map and designate mineral resources of long-term commercial significance because exploiting these resources generally will have the lowest environmental, economic, and social costs (Lingley and Jazdzewski, 1994). The State Department of Natural Resources, or counties following the Department's methodology, are preparing maps detailing the distribution, thickness, and quality of aggregate resources. Yakima, Klickitatt, and Clallam Counties are using aggregate resource maps to zone a 20-year supply of aggregate and protect them from conflicting land uses. The protections include notification of adjacent landowners, recognition that aggregation extraction is the highest and best use of some lands, and other measures (William Lingley, Jr., Washington Department of Natural Resources, written communication, 07 Oct 02).

When the planning community ignores aggregate, management of those resources is left to chance. Management by default commonly results in unintended consequences including sterilization of resources, juxtaposition of incompatible land uses, negative impacts to traffic, unacceptable changes to the landscape, and undesirable environmental impacts. Today, we are in a situation where it is extremely difficult to obtain necessary permits to initiate new aggregate operations. Bauer (1991) concluded that local units of government were unwilling or seem unprepared to deal objectively with the conflict between regional needs and local opposition.

Dunn (1983) attempted to explain, and bring reason to, this conflict in his paper The Dispersed Benefit Riddle. The context of the riddle is: The benefits of aggregate development are dispersed over very large areas, but the community where extraction occurs suffers most of the adverse consequences of resource development. The regional benefits are not usually considered in the local permitting process, and if the resource operation is denied there usually are additional broader costs such as longer haul routes resulting in more truck traffic, noise, accidents, and more hydrocarbons released to the atmosphere. Any gain by the local community is usually at the expense of the greater public and greater environment. The riddle is "When a political entity is evaluating whether or not to develop or improve a resource, how can we as a nation be sure that the dispersed [regional] benefits of use of that resource are adequately weighed in the final decision?" (Dunn, 1983, pg. 1). Sustainability may provide the answer to that decadesold question.

\section{Sustainable Management of Aggregate Resources}

The term "sustainability" dates back to the 1980 World Conservation Strategy, and was given prominence in Our Common Future, otherwise known as the "Bruntland Commission Report” (World Commission on Environment and Development, 1987). 
That report defines sustainable development as "development that meets the needs of the present without compromising the ability of future generations to meet their own needs." (World Commission on Environment and Development, 1987, pg. 43).

In the simplest sense, the "manufactured capital" and "natural capital" (i.e. natural resources) that one generation passes on to the next must be maintained or enhanced in order to achieve sustainable development (World Commission on Environment and Development, 1987). In terms of non-renewable resource such as natural aggregate, their use reduces the natural resources, but unlike many non-renewable resources, the potential supply of aggregate resources on a worldwide scale is so large that "finite" has no practical meaning.

But this does not mean aggregate can indiscriminately be exploited. Aggregate is in short supply in many localities, and should be carefully managed. Furthermore, development of aggregate resources must not endanger the natural systems that support life on earth - the atmosphere, the waters, the soils, and biota. Consequently, having an accessible regional supply of aggregate resources takes on great significance because transporting aggregate long distances not only adds to the overall cost of the product, but as described above in the "Dispersed Benefit Riddle," it also adds to the overall cost to the environment.

The government, industry, and the public must cooperate at the regional and local planning levels for sustainable aggregate extraction to be successful. To ensure the sustainability of aggregate resources, each of the primary stakeholders - government, industry, public, and other non-governmental organizations - must accept certain responsibilities (Langer and others, in press). The government has the responsibility to develop the policies, regulatory framework, and economic incentives that provide the climate for success. The industry must work to be recognized as a responsible corporate and environmental member of the community. The public and non-governmental organizations have the responsibility to become informed about aggregate resource management issues. All stakeholders have the responsibility to identify and resolve legitimate concerns, by constructively contributing to a decision-making process that addresses, not only their own, but a wide range of objectives and interests.

Governments have a variety of tools that they can use to encourage sustainability including laws, policies, guidelines, and incentives. Many countries, at different levels (e.g. national, state, regional, provincial, municipal) have enacted laws to protect water, air, endangered species and other aspects of the environment. These laws are an integral part of sustainability.

Governments of many provinces or territories in Canada and Australia, and many of the countries within the European Union and elsewhere, have elaborated national minerals policies that recognize minerals and mining in general, and the aggregate industry in particular, as key sectors contributing to jobs, wealth, and a high quality of life for its citizens. For example, Planning for the Supply of Aggregates in England (Department of the Environment, Transport, and the Regions, 2000), identifies nine key issues: 1) defining the need for aggregates, 2) assessing the supply of aggregates, 3) estimating the future demand for aggregates, 4) considering imports and exports, 5) considering inter-regional supplies, 6) considering multimodal transportation of aggregate, 7) assessing and mitigating environmental impacts of aggregate development, 
8) identifying preferred areas for aggregate extraction, and 9) planning for future development of aggregate resources.

There is no specific process that must be followed when applying sustainable management of aggregate resources but, in general, the processes followed are iterative, and consist of a number of steps including: 1) identification of the key issues, which generally are elaborated in policy documents, 2) elaboration of the objectives that describe what you want to accomplish, 3) establishment of specific targets that express the desired results, 4) development of specific actions that describe the steps to reach the target, 5) identification of indicators that measure progress as well as the affect of your efforts on the natural and human systems, and 6) monitoring, feedback and regular reconsideration of requirements as events develop. The hierarchy of Sustainable Resource Management (modified from Langer and others, in press) is as follows:

Key issue(s) Objective(s) Target(s)

Action(s)

Indicator(s) Feedback

Indicators deserve special mention. Indicators are specific to the target and actions, but the indicators applied to sustainable development of aggregate resources tend to be similar and can be represented by seven indicators from Department of the Environment, Transport, and the Regions (2000), which include: 1) proportion of supplies coming from preferred areas for extraction, 2) proportions coming from environmentally sensitive areas, 3 ) proportion of primary (natural) aggregates compared to secondary and recycled, 4) amount of aggregates per unit of construction output, 5) area of land undergoing extraction, 6) area of land restored, and 7) proportion of sites covered by modern operating planning conditions.

The Intra-Regional Plan for the Extractive Industry (PIAE) for the Province of Modena, Italy, can serve as a specific example of sustainable management of aggregate resources (Langer and others, in press). Modena Province is updating the PIAE, and has included many elements common to sustainability in the revised plan. The plan is based on the polo estrattivo, which is an area typified by the prevalence of quarrying activities, including the intervening and surrounding territory that is exposed to quarrying impacts. The objectives of the PIAE include guaranteeing the availability of aggregates for present and future generations, maximizing the use of alternative materials, minimize the impacts from quarrying, and guaranteeing the reclamation of quarries in a manner consistent with the existing landscape. Various actions are encouraged to reach these objectives including the identification and protection of existing resources, concentration of future quarry development activities in the poli estrattivi, development of more efficient methods to extract resources, use of substitutes and recycled material, and reclamation that is in harmony with the landscape.

Some aggregate companies in the United States have begun implementing some of the concepts of sustainability without waiting for government intervention. This movement involves international aggregate companies, large American aggregate 
companies, as well as smaller companies who have included environmental responsibility in their corporate philosophy and have initiated aggressive environmental management systems. But actions by the aggregates industry are only part of the process, and sustainable management of aggregate resources should included planning efforts for sustainability.

Minnesota is a pioneering state in both areas of aggregate resource mapping and sustainable community management. During the last decade, Minnesota has taken actions that have won it recognition as one of three leading States in applying principles aimed at achieving environmental and economic sustainability in the United States (Resource Renewal Institute, 2001). Perhaps it will also lead the way in instituting measures for sustainable aggregate resource management.

Minnesota's Governor and the Minnesota Environmental Quality Board convened the Minnesota Sustainable Development Initiative in 1993. The group's final report, Redefining Progress: Working Toward a Sustainable Future, included the recommendation to inventory the State's natural resources. The Minnesota Round Table on Sustainable Development (MRTSD) grew out of the initiative, and was the main forum for advancing its goals and principles. Its flagship report Investing in Minnesota's Future, (MRTSD, 1998), elaborated five principles of sustainable development, the third of which - Conservation - makes note of the need to make wise and efficient use of Minnesota's renewable and non-renewable resources. Minnesota Statutes 2001 4A.07 mandated the preparation of a planning guide for local units of government to plan for sustainable development. That guide, Under Construction - Tools and Techniques for Local Planning (Minnesota Planning, 2002) describes aggregate as a potential community asset, and recommends that a county's natural aggregate resources should be recognized in a land use element.

Sustainable resource management, and finding an answer to the "Dispersed Benefit Riddle," would be less difficult if all conflicts between regional aggregate resource needs and local impacts had solutions that would leave everyone better off. This is seldom the case, and there are usually winners and losers. Furthermore, experience gained through the application of Integrated Resource Management, which is another form of consensus-driven planning, indicates that integrated resource management is most successful when the governing bodies have the authority to set direction and establish order (Walther, 1987).

But as the amount of accessible land that is underlain with suitable aggregate resources diminishes, inequalities increase. Therefore, our inability to promote the common interest in sustainable development is often a product of the relative neglect of economic and social justice. The longer we wait to implement sustainable resource management principles, the more difficult it becomes to implement sustainable resource management. (World Commission on Environment and Development, 1987; Walther, 1987)

\section{Summary}

Throughout the first half of the $20^{\text {th }}$ century, a relatively low demand for aggregate combined with a general unawareness of society's place in, and responsibility 
to the environment, created a situation where aggregate producers in the United States were highly successful, and equally unfettered, in their efforts to meet America's demands for quality sand, gravel, and crushed stone resources. However, changes that have taken place throughout the last half of the $20^{\text {th }}$ century have resulted in a situation where aggregate producers are finding it extremely difficult to locate and permit accessible, economically developable resources. This situation has come about for a variety of reasons including resource sterilization, environmental concerns, citizen involvement in land-use decisions, and variable planning attitudes and requirements toward aggregate resource availability. There is no going back.

There have been a limited number of attempts to identify and protect quality aggregate resources for future use, and these attempts have met with mixed success. Those that have been most successful have an associated incentive or enforcement capacity. In spite of those efforts, local decision-makers commonly are in a quandary when it comes to balancing the regional needs for aggregate with local concerns for the health, safety, and comfort of their constituents.

The management of aggregate resources through the application of sustainable resource management principles might provide a solution to the decision-makers' dilemma. Sustainable management is a highly flexible tool, and it commonly consists of six general steps: 1) elaboration of key issues in policy documents, 2) elaboration of objectives, 3) establishment of specific targets that express the desired results, 4) development of specific actions that describe the steps to reach the target, 5) identification of indicators that measure progress and the affects of actions on the natural and human systems, and 6) monitoring, feedback and regular reconsideration of requirements as events develop.

In order for sustainable resource management to be successful, government, industry, and the public must cooperate at the regional and local planning levels. To ensure the sustainability of aggregate resources, each of the primary stakeholders government, industry, public, and other non-governmental organizations - must accept the responsibility to identify and resolve legitimate concerns, by constructively contributing to a decision-making process that addresses, not only their own, but a wide range of objectives and interests.

\section{Epilog}

James Coxey spoke about the need for a mineral policy at the Fifth Forum on Geology of Industrial Minerals (Hoover, 1970). He said,

"It is a national disgrace that in a country as talented and affluent as America we should lack a clearly defined concept for the wellbeing of our natural resources - a concept that could be accepted and uniformly applied to all levels of government, by all of industry and by all of our people."

Over thirty years later we still have not found that elusive concept for the well being of our natural resources. The time to act is now! 


\section{References:}

Ad Hoc Aggregate Committee, 1998, Minnesota's aggregate resources - Road to the $21^{\text {st }}$ century: Ad Hoc Aggregate Committee for the Aggregate Resources Task Force, St. Paul, Minn., 34 p., http://www.commissions.leg.state.mn.us/aggregate.resources/aggtf98.pdf

Aggregate Resources Task Force, 2000, Aggregate Resources Task Force final report to the Minnesota Legislature: Aggregate Resources Task Force, St. Paul, Minn., 38p.

Bates, R.L., 1969, Geology of the industrial rocks and minerals: New York, Dover Publications, Inc., 459 p.

Bauer, A.M., 1991, Mineral resource management programs and the construction aggregate industry: Planning and Zoning News, April, 1991, Planning and Zoning Center, Inc., Lansing, Mich., p. 5-7.

Bauer, A.M., 1993, Land use - conflicts and resolutions: Integrating aggregate mining into the planning process, in Sidder, G.B., Sims, P.K., eds., Industrial minerals Today and Tomorrow: The raw materials to build the upper Midwest - workshop proceedings: Minnesota Geological Survey Report of Investigations 42, p. 42-47.

Beeby, D.J., 1998, Successful integration of aggregate data in land-use planning - A California case study, in Bobrowsky, P. T., ed., Aggregate resources - A global perspective: A.A, Balkema, Rotterdam, Netherlands, p. 27-50.

Bingham, Nancy, 1994, Mining's image -- What does the public really think?: Mining Engineering, v. 46, no. 3, p. 200-203.

Bliss, J.D., Stanley, M.C. and Long, K.R., 2002, Role of megaquarries in future aggregate supply: San Luis Obispo, Calif., Aug. 13-16, 53rd Annual Highway Geology Symposium, p. 303-315.

Bolen, W.P., 2000, Sand and gravel, construction: U.S. Geological Survey Minerals Yearbook, p. $66.1-66.4,16$ tables.

Crosby, E.J., Hansen, W.R., and Pendleton, J.A., 1978, Guiding the development of gravel deposits and of unstable ground, in Robinson, G.D., and Spieker, A.M., 1978, Nature to be commanded - Earth-science maps applied to land and water management: U.S. Geological Survey Professional Paper 950, p. 28-41.

Department of the Environment, Transport, and the Regions, 2000, Planning for the supply of aggregates in England: Department of the Environment, Transport, and the Regions, Minerals and Waste Planning Division, Draft Consultation Paper, 70 p.

Dunn, J.R., 1983, Dispersed benefit riddle, in, Ault, C.R., and Woodard, G.S., eds., Proceedings of the 18th Forum on Geology of Industrial Minerals: Indiana Geological Survey Occasional Paper 37, p. 1-9.

Goldman, H.B., 1959, Urbanization and the mineral industry: San Francisco, Mineral Information Service, California State Division of Mines, $11 \mathrm{p}$.

Guillet, G.R., 1980, Constraints of industrial minerals -The Ontario experience, in Dunn, J.R., Fakundiny, R.H., and Rickard, L.V., eds., $14^{\text {th }}$ Annual Forum on the Geology of Industrial Minerals: New York State Museum Bulletin 436, p. 21-26.

Hoover, K.V., ed., 1970, Proceedings - Fifth Forum on Geology of Industrial Minerals: Pennsylvania Geological Survey Bulletin M64, 278 p. 
Hudec, P.P., 1969, Long range planning for aggregate materials in metropolitan New York, in Hoover, K. V., ed., Fifth Forum on the Geology of Industrial Minerals: Pennsylvania Bureau of Topographic and Geologic Survey Mineral Resources Report M64, p. 165-177.

Kiersch, G.A., 1955, Engineering geology: Historical development, scope, and utilization: Quarterly of the Colorado School of Mines, v. 50, no. 3, 122 p.

Kuff, K.R., 1984, Rates of preemption of sand and gravel deposits in an urban area, in Glaser, J.D., and Edwards, J., eds., Twentieth Forum on the Geology of Industrial Minerals: Maryland Geological Survey Special Publication 2, p. 73-79.

Langer, W.H., 1988, Natural aggregates of the conterminous United States: U.S. Geological Survey Bulletin 1594, 33 p., 2 plates, scale 1:5,000,000. , 1998, A history of aggregate development and geology - the past is the key to the future, in, Bélanger, M., Clark, T., and Jacob, H.L., 33rd Forum on Geology of Industrial Minerals, Quebec, Canada, Proceedings: Canadian Institute of Mining, Metallurgy, and Petroleum, Special Volume 50, p. 27-40. , 2001, Environmental Impacts of Mining Natural Aggregate, in Bon, R.L., Riordan, R.F., Tripp, B.T., and Krukowski, S.T., eds., Proceedings, $35^{\text {th }}$ Forum on the Geology of Industrial Minerals: Utah Department of Natural Resources Miscellaneous Publication 01-2, p. 127-138. , 2002, An overview of aggregate resources in the United States, in Scott, P.W., and Bristow, C.M., eds., Industrial minerals and extractive geology: The Geological Survey, London, p. 17-42.

Langer, W.H., and Glanzman, V.M., 1993, Natural aggregate - Building America's future: U.S. Geological Survey Circular 1110, 39 p.

Langer, W.H., Giusti, Cecilia, and Barelli, Giorgio, in press, Sustainable development of natural aggregate - With examples from Modena Province, Italy: Society for Mining, Metallurgy, and Exploration, Inc., Preprint, Littleton, Colorado.

Leighton, M.W., 1991, Industrial minerals resource identification and evaluation, in Bush, A.L., and Hayes, T.S., eds., Industrial Minerals of the Midcontinent Proceedings of the Midcontinent Industrial Minerals Workshop: U.S. Geological Survey Bulletin 2111, p. 9-20.

Lenhart, W.B., 1947, Business booming in the west: Rock Products v. 50, no. 2, p. 88-93, $125,126$. , 1960, Sand and gravel, in Gillson, J.L., ed., Industrial minerals and rocks: The American Institute of Mining, Metallurgical, and Petroleum Engineers, New York, p. 733-758.

Lingley, W.S., Jr., and Jazdzewski, S.P., 1994, Aspects of growth management planning for mineral resource lands: Washington State Department of Natural Resources, Washington Geology, v. 22, no. 2, p. 36-45.

Lüttig, G.W., 1994, Rational management of the geo-environment - A view in favour of “Geobased Planning”, in Lüttig, G.W., ed., Aggregates - Raw materials' giant: Report on the 2nd International Aggregate Symposium, Erlangen, p. 1-34.

Marshall, H.E., and Maxey, J.S., 1950, The role of the geologist in constructing Ohio's highways: Engineering Experiment Station News, v. 12, no. 2, p. 12-14.

Mikulic, D.G., and Goodwin, J.H., 1984, Urban encroachment on dolomite resources of the Chicago area, Illinois, in Glaser, J.D., and Edwards, J., eds., Twentieth Forum 
on the Geology of Industrial Minerals: Maryland Geological Survey Special Publication 2, p. 125-131.

Minnesota Planning, 2002, Under construction - Tools and techniques for local planning: Minnesota Planning, St. Paul, Minn., 192 p.

MRTSD, 1998, Investing in Minnesota's future - An agenda for sustaining our quality of life: Minnesota Round Table on Sustainable Development (MRTSD), Minnesota Environmental Quality Board, 24 p.

New England Governors' Conference, 1995, Construction aggregate resources of New England - An analysis of supply and demand: New England Governors' Conference, Inc., Boston, 10 sections, variously paged.

Poulin, R., Pakalnis, R.C., and Sinding, K., 1994, Aggregate resources - Production and environmental constraints: Environmental Geology, v. 23, p. 221-227.

Reilly, B. 2000, Rapid industry consolidation expected to continue. Aggregates Manager, v. 4 , no. 12 , p 31-34.

Resource Renewal Institute, 2001, The state of the States - Assessing the capacity of States to achieve sustainable development through green planning: Resource Renewal Institute, San Francisco, 104p.

Schwochow, S.D.,1980, The effects of mineral conservation legislation on Colorado's aggregate industry, in Proceedings of the Fifteenth Forum on Geology of Industrial Minerals: Colorado Geological Survey Resource Series no. 8, p. 30-39.

Schwochow, S.D., Shroba, R.R., and Wicklein, P.C., 1974, Sand, gravel, and quarry aggregate resources - Colorado Front Range counties: Colorado Geological Survey Special Publication 5-A, 43 p.

Shadmon, A., 1968, Quarry site surveys in relation to country planning, in International Geological Congress: Report of the Twenty-Third Session, Czechoslovakia, v. 12, p. 125-132.

Shaler, N.S., 1895, Preliminary report on the geology of the common roads of the United States: U.S. Geological Survey $15^{\text {th }}$ Annual Report, p. 255-306 , 1896, The geology of the road-building stones of Massachusetts, with some consideration of similar materials from other parts of the United States: U.S. Geological Survey $16^{\text {th }}$ Annual Report, p. 283-341.

Siebert, H.L., 1969, Connecticut's declining sand and gravel resources, in Hoover, K.V., ed., Fifth Forum on the Geology of Industrial Minerals: Pennsylvania Bureau of Topographic and Geologic Survey Mineral Resources Report M64, p. 43-54.

Southwick, D.L., Jouseau, M., Meyer, G.N., Mossler, J.H., and Wahl, T.E., 2000, Aggregate resources inventory of the seven-county metropolitan area, Minnesota: Minnesota Geological Survey Information Circular 46, 91 p.

Soule, J.M., 1974, Gravel resources, urbanization and future land use, Front Range Urban Corridor, Colorado: U.S. Geological Survey Open File Report 74-178, 29 p.

Tepordei, V.V., 1997, Natural aggregates - Foundation of America's future: U.S. geological Survey Fact Sheet FS 144-97, 4 p. , 2000, Stone, crushed: U.S. Geological Survey Minerals Yearbook, p. 73.1 73.6, 26 tables.

Thoenen, J.R., 1954, Sand and gravel industry produces largest tonnage of minerals: Rock Products, v. 57, no. 5, p. 104, 106, 108, 111-116. 
U.S. Department of Labor, 1981, Report to the Denver Construction Committee on sand and gravel operations at Chatfield Dam and Recreation Area: U.S. Department of Labor, Office of Construction Industry Services, $4 p$. and exhibits A-I.

U.S. Geological Survey, 2002, Mineral commodity summaries 2002: U.S. Geological Survey Mineral commodity summaries, $197 \mathrm{p}$.

Walther, Pierre, 1987, Against idealistic beliefs in the problem-solving capacities of integrated resource management: Environmental Management, v. 11, no. 4, p. 439-446.

World Commission on Environment and Development, 1987, Our common future: The World Commission on Environment and Development, Oxford University Press, Oxford, $400 \mathrm{p}$.

Weaver, B., 1995, Overview of the aggregate industry, SME 1995 Annual Meeting: Society for Mining, Metallurgy, and Exploration, Inc., Preprint No. 95-222, 3p.

Werth, J.T., 1980, Sand and gravel resources - Protection, regulation, and reclamation: American Planning Association Report no. 347, 33 p.

Wilburn, D.R., and Langer, W.H., 2000, Preliminary report on aggregate use and permitting along the Colorado Front Range: U.S. Geological Survey Open-File Report 00-258, $22 \mathrm{p}$. 